\title{
A protein map of the yeast activated spliceosome as obtained by electron microscopy
}

\author{
CHENGFU SUN, ${ }^{1}$ NORBERT RIGO, ${ }^{1}$ PATRIZIA FABRIZIO, BERTHOLD KASTNER, and REINHARD LÜHRMANN \\ Department of Cellular Biochemistry, Max Planck Institute for Biophysical Chemistry, 37077 Göttingen, Germany
}

\begin{abstract}
We have elucidated the spatial arrangement of proteins and snRNP subunits within the purified spliceosomal $B^{\text {act }}$ complex from Saccharomyces cerevisiae, using negative-stain immunoelectron microscopy. The $\mathbf{B}^{\text {act }}$ spliceosome exhibits a mushroom-like shape with a main body connected to a foot and a steep and a shallow slope. The U5 core components, including proteins Snu114 and Prp8, are located in the main body and foot, while Brr2 is on the shallow slope. U2 snRNP components and the RNA helicase Prp2 were predominantly located in the upper regions of both slopes. While several proteins of the "nineteen complex" are located on the steep slope, Prp19, Cef1, and the U6 snRNA-binding protein Cwc2 are on the main body. Our results also indicate that the catalytic core RNP of the spliceosome resides in its main body. We thus assign distinct domains of the $B^{\text {act }}$ complex to its snRNP and protein components, and we provide first structural insights into the remodeling events at the spliceosome during its transformation from the $B$ to the $B^{\text {act }}$ complex.
\end{abstract}

Keywords: B $^{\text {act }}$ complex; electron microscopy; immunolabeling; protein localization; spliceosome

\section{INTRODUCTION}

The spliceosome is a highly dynamic molecular machine that assembles de novo for each new round of pre-mRNA splicing by the sequential recruitment to the intron of the U1, U2, and U4/U6.U5 small nuclear ribonucleoproteins (snRNPs) and numerous non-snRNP proteins. The snRNPs comprise an snRNA molecule and numerous proteins, reviewed elsewhere (Will and Lührmann 2011). All the spliceosomal snRNAs, except the U6 snRNA, are characterized by a 2,2,7-trimethylguanosine $\left(\mathrm{m}_{3} \mathrm{G}\right)$ cap structure at their $5^{\prime}$ ends (Reddy et al. 1974; Branlant et al. 1982; Busch et al. 1982) and are tightly bound by a heptameric, ring-shaped Sm protein complex near their respective $3^{\prime}$ end. The U6 snRNA has a $\gamma$-methylguanosine cap at its $5^{\prime}$ end (Singh and Reddy 1989) and an LSm ring at its $3^{\prime}$ end. The spliceosome undergoes a series of remodeling steps that are driven by eight conserved DExD/H-box ATPases or RNA helicases (Cordin et al. 2012; Cordin and Beggs 2013). During the course of spliceosome assembly, the snRNPs bind to the pre-mRNA in a stepwise manner. Initially, U1 snRNP forms a base-pairing interaction with the $5^{\prime}$ splice site (SS) of the intron; recruitment of the U2 snRNP to the branch-point (BP) sequence (BPS) yields the A complex. U2 snRNA forms a base-pairing

\footnotetext{
${ }^{1}$ These authors contributed equally to this work.

Corresponding authors: reinhard.luehrmann@mpibpc.mpg.de, pfabriz1@mpibpc.mpg.de, bkastne@mpibpc.mpg.de

Article published online ahead of print. Article and publication date are at http://www.rnajournal.org/cgi/doi/10.1261/rna.057778.116.
}

interaction with the BPS nucleotides, while several proteins of the U2-associated SF3a and SF3b complexes stabilize the binding of the U2 snRNP to the intron by interacting with intron nucleotides upstream and downstream from the BPS (Gozani et al. 1996; Schneider et al. 2015). The U4/U6.U5 tri-snRNP, in which the U4 and U6 snRNAs are extensively base paired to one another, associates with the A complex, and a short helix between the $5^{\prime}$ end of the U2 and the $3^{\prime}$ end of the U6 snRNAs (U2/U6 helix II) is formed. Immediately before, or concomitantly with, the integration of the tri-snRNP, the U1-5'SS interaction is disrupted (Staley and Guthrie 1999) and the U1 snRNP is destabilized (Fabrizio et al. 2009). This event frees the $5^{\prime}$ SS and allows it to base pair with the ACAGA box of U6 snRNA (Kandels-Lewis and Séraphin 1993; Lesser and Guthrie 1993), resulting in formation of the precatalytic B complex in which the catalytic RNA network that forms the spliceosome's catalytic center is not yet established.

Activation of the spliceosome, yielding the $\mathrm{B}^{\text {act }}$ complex, involves unwinding of the U4/U6 duplex by the RNA helicase Brr2 (Raghunathan and Guthrie 1998). This allows the U6 snRNA to interact with the U2 snRNA and to form the U2/U6 helices Ia and Ib, and an internal stem-loop (ISL) that is homologous to domain $\mathrm{V}$ of self-splicing group II

(C) 2016 Sun et al. This article is distributed exclusively by the RNA Society for the first 12 months after the full-issue publication date (see http://rnajournal.cshlp.org/site/misc/terms.xhtml). After 12 months, it is available under a Creative Commons License (Attribution-NonCommercial 4.0 International), as described at http://creativecommons.org/licenses/by-nc/4.0/. 
introns (Keating et al. 2010). Concomitantly with these events, the U5 snRNA loop I base pairs with the $5^{\prime}$ exon adjacent to the 5'SS (Wyatt et al. 1992; Sontheimer and Steitz 1993); at the same time as these RNA rearrangements, the $\mathrm{U} 1$ and $\mathrm{U} 4$ snRNAs, all U1 and U4/U6 snRNP proteins, the U4/U6.U5 tri-snRNP proteins, and several of the U5 snRNP proteins (except for Brr2, Prp8, Snu114 and the Sm proteins) are released from the spliceosome (Fig. 1A). All the U2 snRNP proteins, including Leal and the SF3a and SF3b complexes, remain associated with the $\mathrm{B}^{\text {act }}$ complex (Caspary and Séraphin 1998; Fabrizio et al. 2009). Several proteins that are loosely associated with the $\mathrm{B}$ complex, including the 10 proteins of the Prp19 core complex (NTC), and all three proteins of the RES (retention and splicing) complex, are stably integrated into the $\mathrm{B}^{\text {act }}$ complex (Dziembowski et al. 2004; Fabrizio et al. 2009; Hogg et al. 2010). Several new proteins not found in the $\mathrm{B}$ complex are recruited to the $\mathrm{B}^{\text {act }}$ complex (these proteins are termed $\mathrm{B}^{\text {act }}$ proteins). Therefore, the yeast S. cerevisiae $\mathrm{B}^{\text {act }}$ complex comprises the $\mathrm{U} 2 / \mathrm{U} 6 / \mathrm{U} 5 /$ premRNA interaction network (Datta and Weiner 1991; Wu and Manley 1991; Madhani and Guthrie 1994) and approximately 40 proteins (summarized in Supplemental Fig. S1), and it represents the spliceosome after activation and before the catalysis of step 1, in which the major RNA rearrangements needed to form an active catalytic center are thought to have occurred (Fica et al. 2014).

For catalytic activation, the $\mathrm{B}^{\text {act }}$ complex is remodeled by the RNA helicase Prp2 in cooperation with its G-patch protein cofactor Spp2, yielding the B* complex (Roy et al. 1995; Silverman et al. 2004; Warkocki et al. 2009, 2015), in which step 1 catalysis occurs, whereby the $2^{\prime}$ hydroxyl group of the $\mathrm{BP}$ adenosine attacks the $5^{\prime} \mathrm{SS}$, generating the cleaved-off $5^{\prime}$ exon and the intron-lariat (IL)-3'exon intermediates (Chiu et al. 2009; Warkocki et al. 2009). The newly formed C complex catalyzes step 2 of splicing, leading to exon ligation (Horowitz 2012). The mature mRNA then dissociates from the intron-lariat spliceosome (ILS).

The dynamic nature of the spliceosome and the compositional and conformational heterogeneity of the purified complexes together make structural analysis challenging. Recently, medium- to high-resolution three-dimensional (3D) structures of the U4/U6.U5 tri-snRNP from S. cerevisiae (Nguyen et al. 2015, 2016a; Wan et al. 2016) and from human (Agafonov et al. 2016) were determined by electron cryo-microscopy (cryo-EM). Likewise, the cryo-EM structure of S. pombe's endogenous post-catalytic ILS was elucidated at a resolution of $3.6 \AA$ (Yan et al. 2015; for review, see Nguyen et al. 2016b). The latter structure revealed that the spliceosomal RNA network after splicing catalysis is structurally similar to the catalytic core of self-splicing group II introns. It also revealed that the RNA core is embedded in an intricate protein-RNA interaction network, with Prp8 playing a central role in docking the catalytic RNA elements, and other proteins-for example Cef1/CDC5-making further contacts with the RNA core. However, Brr2 and the
A

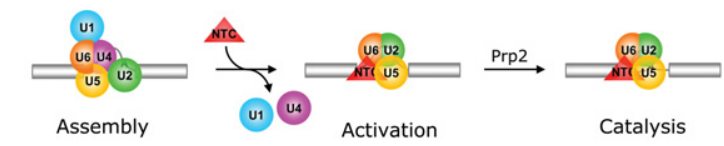

B C

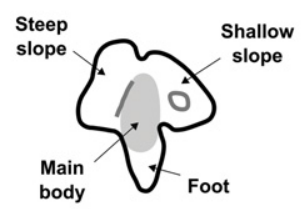

C

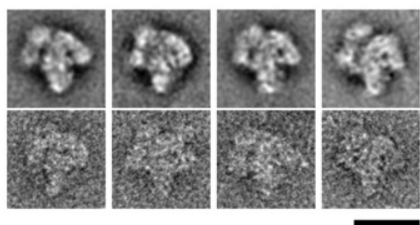

D

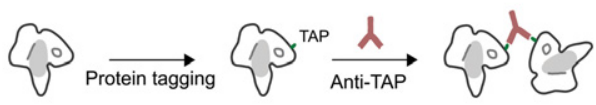

E

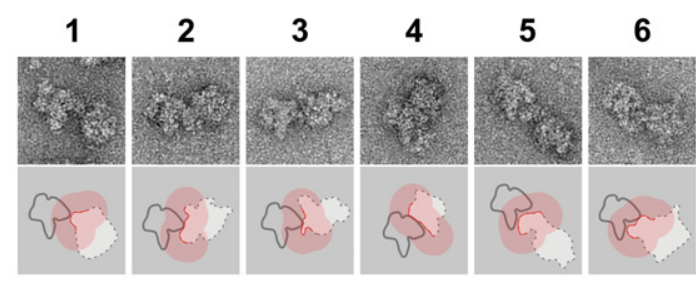

$\mathbf{F}$

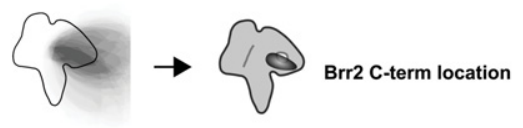

FIGURE 1. Structure of the yeast spliceosomal $\mathrm{B}^{\text {act }}$ complex and strategy used to locate $\mathrm{C}$-terminally TAP-tagged Brr2 within $\mathrm{B}^{\text {act }}$ complex dimers created by anti-TAP antibody. (A) Schematic depiction of splicing events occurring during spliceosome activation. The assembled spliceosomal B complex undergoes dramatic changes, including the release of $\mathrm{U} 1$ and U4, stable recruitment of NTC and other splicing factors, and formation of the catalytic RNA network, to generate the $\mathrm{B}^{\text {act }}$ complex, which then is activated for step 1 catalysis by the ATPase/helicase Prp2 and its cofactor Spp2. (B) Domains of the yeast B ${ }^{\text {act }}$ complex. The $\mathrm{B}^{\text {act }}$ complex exhibits a mushroom-like shape consisting of the steep slope, the shallow slope, and the main body, with a foot domain protruding downward from the bottom of the main body. A gap along the interface between the steep slope and the main body is shown by a short line, and a hole under the shallow slope is shown by a closed loop. The main body is colored gray. $(C)$ Four major class averages and corresponding raw EM images of yeast $\mathrm{B}^{\text {act }}$. $\mathrm{B}^{\text {act }}$ complexes were purified from Saccharomyces cerevisiae bearing a TAP tag at $\mathrm{C}$ terminus of Cwc2 and viewed in the electron microscope. Class averages are shown in the upper panel and raw images in the lower panel. The scale bar represents $30 \mathrm{~nm}$. (D) Schematic depiction of anti-TAP antibody-induced $\mathrm{B}^{\text {act }}$ complex dimerization that is used to locate a TAP-tagged protein in the spliceosomal $\mathrm{B}^{\text {act }}$ complex. The $\mathrm{B}^{\text {act }}$ complexes are depicted in the main view, the TAP tag are shown in green, and the antibodies with their characteristic $Y$ shape in brown. (E) Six representative Brr2 C-terminally TAP-tagged $\mathrm{B}^{\text {act }}$ dimers formed with the anti-TAP antibody. The upper panel shows the raw images. The lower panel shows the corresponding schematic depiction and possible area of TAP tag location within the main-view particle. The outline of the marker particle at the dimerization interface with the main-view particle is drawn as a red line, and the area within $14 \mathrm{~nm}$ of the marker particle outline at the particle interface is shown as a transparent red area. $(F)$ The left panel shows the area of maximum overlap deduced from overlaying all dimers of the data set (dark gray). The right panel shows the final location in the $\mathrm{B}^{\text {act }}$ complex depicted as a transparent dark area. 
U2 snRNP proteins that make up the SF3a and SF3b complexes are missing from the endogenous ILS structure (Yan et al. 2015). A medium-resolution structure of a human $C$ complex assembled in vitro revealed only approximately the location of the U5 and U2 snRNP components (Golas et al. 2010); therefore, their spatial arrangement in active spliceosomes immediately before and after step 1 catalysis remains to be elucidated.

So far, the structure of the $\mathrm{B}^{\text {act }}$ complex has only been studied by 2D EM. 2D class averages of $\mathrm{B}^{\text {act }}$ complexes from yeast and from human showed a similar mushroom-like appearance (Fabrizio et al. 2009; Bessonov et al. 2010). Comparison with the respective $\mathrm{B}$ and $\mathrm{C}$ complexes revealed that the morphology of human and yeast $\mathrm{B}^{\text {act }}$ spliceosomes changes significantly during activation and catalysis (Fabrizio et al. 2009; Bessonov et al. 2010). This indicated that major 3D structural rearrangements occur during the transitions from the $\mathrm{B}$ to the $\mathrm{B}^{\text {act }}$ to the $\mathrm{C}$ complex and probably also to the post-catalytic ILS.

We previously reported a negative-stain EM-based method to locate spliceosomal proteins in the yeast B complex (Rigo et al. 2015). This work represented the first extensive mapping of a fully assembled spliceosome and led to a better understanding of its architecture. This method makes use of genetically TAP-tagged proteins that are incorporated into the spliceosome. The spliceosomal particles are dimerized specifically by the addition of anti-TAP antibodies and the dimeric spliceosomes were used to localize proteins in negative-stain EM images (Rigo et al. 2015). The protein locations revealed extensive similarities with those previously mapped in the yeast tri-snRNP (Häcker et al. 2008) and also with the positions of proteins in the recently determined 3D cryo-EM structure of the tri-snRNP from S. cerevisiae (Nguyen et al. 2015, 2016a; Wan et al. 2016). This similarity was revealed by fitting the tri-snRNP into the $\mathrm{B}$ complex (Rigo et al. 2015).

Here we used this approach to conduct extensive mapping of protein positions in the yeast $\mathrm{B}^{\text {act }}$ complex. We located several proteins from the various subcomplexes associated with the $\mathrm{B}^{\text {act }}$ complex (asterisks in Supplemental Fig. S1), including Brr2, the U2 SF3a/b components, and those that were suggested to play a role in the formation of the catalytic RNP core such as Cwc2, Cwc21, and Cwc24 (Grainger et al. 2009; McGrail et al. 2009; Ohrt et al. 2012; Rasche et al. 2012). We also located the $m_{3} G$ cap structure of the U2 and U5 snRNAs. These locations represent a comprehensive mapping of the activated $\mathrm{B}^{\text {act }}$ spliceosome. Understanding the organization of snRNPs and non-snRNP proteins at the $\mathrm{B}^{\text {act }}$ stage and comparing it with that in the $\mathrm{B}$ complex provides important insights into the remodeling events necessary for activation and step 1 catalysis. Furthermore, on the basis of extensive knowledge about protein-RNA interactions in the $\mathrm{B}^{\text {act }}$ complex and the recent cryo-EM structures (for review, see Nguyen et al. 2016b) the positions of catalytic RNA elements can be deduced from the respective protein positions.

\section{RESULTS}

\section{Purification, morphology, and immunolabeling of yeast

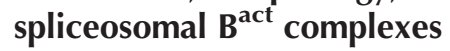

In vitro assembly of spliceosomal complexes in yeast wholecell extract can be stalled at the $\mathrm{B}^{\text {act }}$ stage either (i) by using a wild-type extract and a pre-mRNA construct that is truncated 6 nucleotides (nt) downstream from the BPS and lacks a 3'SS (M3-Actin $\Delta 6$ ) (Fabrizio et al. 2009); or (ii) by using extracts from yeast strains that express a temperature-sensitive Prp2 mutant (prp2-1) (Kim and Lin 1996; Warkocki et al. 2009) together with full-length M3-Actin pre-mRNA. To purify yeast $\mathrm{B}^{\text {act }}$ complexes for subsequent localization of proteins by negative-stain EM we used $\left[{ }^{32} \mathrm{P}\right]$-labeled pre-mRNA with three MS2 coat-protein-binding aptamers at the $5^{\prime}$ end (Zhou and Reed 2003) and incubated it under splicing conditions with yeast whole-cell extract from strains expressing a single spliceosomal protein tagged with the TAP tag (Rigaut et al. 1999). When we assembled $B^{\text {act }}$ complexes by the prp2-1 method (above), we heat-inactivated the Prp2 protein before incubation with the pre-mRNA. Following complex assembly we applied the MS2-MBP (maltose-binding protein) affinity-purification method (Zhou and Reed 2003; Fabrizio et al. 2009) and subjected the purified complexes to ultracentrifugation in a glycerol-density gradient in the presence of glutaraldehyde; this allowed the particles to be separated and (internally) cross-linked in a single step; the latter stabilizes them for examination by negative-stain EM (Kastner et al. 2008).

As observed for other spliceosomal complexes, the $\mathrm{B}^{\text {act }}$ complex is adsorbed to the carbon film of the EM sample grid in one preferential orientation, leading to one predominant viewing angle in electron micrographs (Fabrizio et al. 2009). This we term the "main view" of the $B^{\text {act }}$ complex. A schematic depiction of its $2 \mathrm{D}$ projection and representative class averages, together with raw images, are shown in Figure $1 \mathrm{~B}$ and $\mathrm{C}$. The main view of the $\mathrm{B}^{\text {act }}$ complex has an overall "mushroom-like" shape with a "foot" protruding downward at the bottom center. This main view is asymmetric, with a steep slope shown on the left and a gradual or "shallow" slope on the right. The foot, steep slope, and shallow slope are positioned around a main body that extends into the foot. The overall length of the particle from the bottom of the foot to the upper end of the steep slope is $\sim 32 \mathrm{~nm}$, and the width of the particle, between the outer edges of the steep and the shallow slope, is $\sim 29 \mathrm{~nm}$.

To locate proteins in the yeast $\mathrm{B}^{\text {act }}$ complex, we assembled spliceosomes in vitro in splicing-active yeast extracts from haploid strains expressing a single genetically tagged protein that was incorporated into the complex. We chose the tandem affinity-purification (TAP) tag (Rigaut et al. 1999) that we had already found to be suitable for immunolabeling and immunolocalization studies, both of the yeast tri-snRNP (Häcker et al. 2008) and of the B complex (Rigo et al. 2015). As all 
the yeast strains used in this study were viable, we infer that addition of the TAP tag to these spliceosomal proteins did not affect splicing. The addition of polyclonal rabbit antiTAP antibodies to affinity-purified $\mathrm{B}^{\text {act }}$ complexes containing a single TAP-tagged protein led to spliceosome dimers that were purified and cross-linked by GraFix (Kastner et al. 2008). Negative-stain $E M$ and analysis of $B^{\text {act }}$ complex dimers were performed as previously described for the yeast B complex (Rigo et al. 2015).

\section{The U5 snRNP proteins are located in the foot, the main body, and the shallow slope of the $B^{\text {act }}$ complex}

After stable integration into the spliceosome, the tri-snRNP undergoes dramatic conformational and compositional changes. All the U1 and U4/U6 snRNP proteins, the U1 and U4 snRNA, and several U5 snRNP proteins leave the spliceosome, and only Brr2, Prp8, Snu114, the Sm ring, and the U5 and U6 snRNA molecules remain in it (Fabrizio et al. 2009). Our previous labeling study of the B complex (Rigo et al. 2015) as well as the recently published 3D structures of the yeast U4/U6.U5 tri-snRNP (Nguyen et al. 2016a; Wan et al. 2016) revealed that the U5 snRNP forms an elongated structure with Brr2 at one end, Prp8 and Snu114 in the middle, and the U5 Sm ring at the other end. Since Brr2 and Prp8 are relatively large proteins (246 and $280 \mathrm{kDa}$, respectively), we set out to locate the $\mathrm{C}$ and $\mathrm{N}$ termini of these proteins and also the $\mathrm{C}$ terminus of Snu114.

To locate the U5 snRNP protein Brr2, we fused a TAP tag to its $\mathrm{C}$ terminus, purified $\mathrm{B}^{\text {act }}$ complexes as described above, added anti-TAP antibodies, and prepared EM specimens from the density-gradient fractions in which the spliceosomal dimers sedimented, corresponding to a sedimentation coefficient of 70S. The radioactivity measured in the fractions of the gradient (Supplemental Fig. S2) showed a peak in the range of $70 \mathrm{~S}$ only when antibodies were added to TAP-tagged $\mathrm{B}^{\text {act }}$ complexes (red curve). Without antibody addition (blue curve) there was no peak in the radioactivity signal in the $70 \mathrm{~S}$ range. In addition, we analyzed the antibody content of the gradient fractions by an enzyme-linked immunosorbent assay (ELISA). The peak in the radioactivity signal at $70 \mathrm{~S}$ colocalizes with a peak in the ELISA signal (green curve), which shows that the shift in sedimentation value of the spliceosomal particles is due to specific interaction with the anti-TAP antibodies. EM images of the particles from the 70S fractions of the gradient (Supplemental Fig. S3) clearly show that the particles were dimeric spliceosomes and that there was no unspecific particle aggregation. A corresponding observation was made for all TAP-tagged spliceosomal proteins that we investigated in this study (Supplemental Figs S2, S3). In most cases only one particle of the dimer binds to the carbon film in the preferred orientation, thus showing the $\mathrm{B}^{\text {act }}$ main view (Fig. 1C); we term this particle the "main-view" particle. For all proteins investigated, we took electron micrographs in sufficient number to obtain a data set of 50-100 "main-view" dimers and applied the localization method described previously (Rigo et al. 2015).

This method makes use of the fact that the distance between the TAP tags of each spliceosome in a dimer cannot exceed $14 \mathrm{~nm}$, as the length of each connecting Fab or Fc arm of the IgG molecule is $7 \mathrm{~nm}$ (Silverton et al. 1977). Both domains of the TAP tag can be involved in anti-TAP antibody binding: the calmodulin-binding peptide (CBP) domain by binding to the antibody's Fab arm and the protein A domain by binding to the Fc arm (schematically depicted in Fig. 1D). If two spliceosomal particles dimerize by the binding of both TAP tags to the Fc domain of a single IgG molecule, then the distance between the two TAP tags can be much shorter than $14 \mathrm{~nm}$. As in most cases the IgG molecule is not discernible in the electron micrographs, we exploit the fact that the TAP tag of the main-view particle is constrained to be within $14 \mathrm{~nm}$ of the outline of the other particle; the latter serves as a marker (henceforth termed "marker particle").

Six $\mathrm{B}^{\text {act }}$ complex dimers, representative of the whole data set of particles bearing a TAP tag at the C terminus of Brr2, are shown in Figure 1E. Three main classes of dimers regarding the relative orientation of the two particles were observed. In one class, the marker particle was connected to the mainview particle either at the bottom corner of the shallow slope (Fig. 1E, frames 1-3), along the entire length of the shallow slope (Fig. 1E, frame 4), or at the bottom edge of the shallow slope, involving the foot (Fig. 1E, frames 5 and 6). To identify the possible area in the main-view particle in which the antibody-binding site can be located, we traced the outline of the second particle (red line in the schematic drawings in the bottom row in Fig. 1E) and extended it to $14 \mathrm{~nm}$ (transparent red area in Fig. 1E).

The red area overlapping with the $\mathrm{B}^{\text {act }}$ main-view particle encompasses all possible antibody-binding sites in the mainview particle of the respective dimer. For all main-view dimers in the data set, this area was determined individually. Next we aligned all these dimers according to the mainview particle, which led to overlapping of the individual areas of possible tag location. The intersection of all these individual areas, appearing as the darkest region at the bottom edge of the shallow slope, touching the main body, was then taken as the final-i.e., most precise-area where the TAP tag, and thus the $\mathrm{C}$ terminus of Brr2, is located (Fig. 1F). In the same way we located the TAP tag of each protein investigated in this study.

We next located the $\mathrm{N}$ terminus of Brr2. In dimers with $\mathrm{N}$-terminally tagged Brr2, the marker particle was connected to the main-view particle by the shallow slope as observed for C-terminally tagged Brr2. However, the marker particle was never found close to the foot. Instead, it was found at the top of the main view and also in contact with the steep slope (Fig. 2A). Because of this distribution of the marker particle, the area in which Brr2's $\mathrm{N}$ terminus is located, resulting from the overlap of all individual areas, was found in the top third 
A

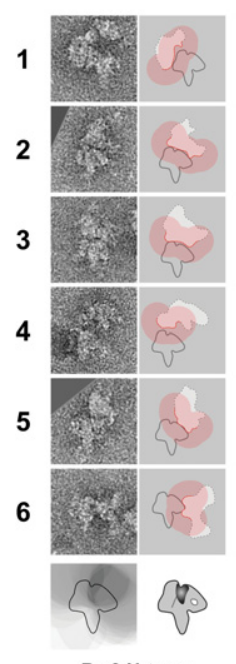

B

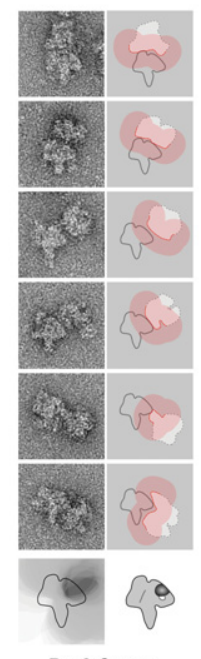

C

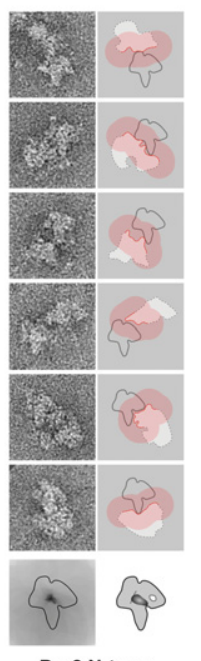

Prp8 N-term
D

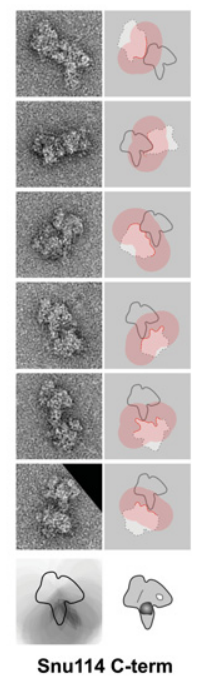

FIGURE 2. Locations of U5 snRNP proteins in the yeast spliceosomal $\mathrm{B}^{\text {act }}$ complex. EM images of $\mathrm{B}^{\text {act }}$ complex dimers were taken at 115,000-fold magnification and dimers with at least one main-view particle were used for localization analysis. For each protein location, representative raw images of six dimers (left panels) and corresponding schematic drawing of the marker particle with the uniform main-view particle (right panels) are shown and numbered from 1 to 6 . At the bottom, the location of the respective protein on the $\mathrm{B}^{\text {act }}$ sketch was deduced by overlaying all dimers in the respective data set (left) and is depicted as a transparent dark area (right). (A) $\mathrm{N}$ terminus of Brr2. (B) C terminus of Prp8. (C) N terminus of Prp8. (D) C terminus of Snul14.

of the shallow slope, extending into the top of the main body (sketch in Fig. 2A, lower right).

The next protein we located was Prp8. As can be seen in Figure $2 \mathrm{~B}, \mathrm{~B}^{\text {act }}$ complex dimers harboring C-terminally tagged Prp8 reveal that the marker particle is attached to the shallow slope only. Applying the analysis method described above, we found the area where the $\mathrm{C}$ terminus of Prp8 is located to occupy the middle third of the shallow slope. When Prp8 was tagged N-terminally, a distribution of marker particles all around the main-view particle was observed, as exemplified by six representative dimers in Figure 2C, which led to the final area where Prp8's N terminus must be located, that is, in the center of the $\mathrm{B}^{\text {act }}$ complex (i.e., the top part of the main body; sketch in Fig. 2C).

We further located the $\mathrm{C}$ terminus of Snu114. As can be seen in Figure 2D, the dimerization occurred at different parts of the main-view particle, and points of attachment were located mainly in the bottom half of the $\mathrm{B}^{\text {act }}$ complex, very often involving the foot. The final area where the $\mathrm{C}$ terminus of Snu 14 was located in the $\mathrm{B}^{\text {act }}$ complex main view thus lies in the bottom part of the main body, where it is connected to the foot (sketch in Fig. 2D). Taken together, in the $\mathrm{B}^{\text {act }}$ complex, the U5 snRNP proteins Prp8 and Snu114 occupy the main body, with Snu114 being located at the bottom of the main body.

\section{The U2 snRNP proteins are located in the upper regions of the steep and the shallow slopes}

In the $\mathrm{B}^{\text {act }}$ complex several SF3a and SF3b complex proteins could be cross-linked to the pre-mRNA intron in a region upstream of the BPS (Schneider et al. 2015). In addition, cross-links across the BP and at the $3^{\prime}$ end of the intron have been found for the SF3b protein Hsh155 (McPheeters and Muhlenkamp 2003; Schneider et al. 2015). The location of U2 snRNP proteins, in particular Hsh155, could indirectly provide information about the location of the U2/pre-mRNA BP helix. To find the position of the U2 snRNP in the $\mathrm{B}^{\text {act }}$ complex, we selected Leal (a protein that serves as a marker for the U2 snRNP's Sm ring; Caspary and Séraphin 1998), three SF3b complex proteins (Cus1, Hsh155, and Rse1), and two SF3a complex proteins (Prp9 and Prp11). For each of these proteins in turn, the TAP tag was introduced at the $\mathrm{C}$ terminus. For all of these $\mathrm{U} 2 \mathrm{snRNP}$ proteins, the resulting $\mathrm{B}^{\text {act }}$ complex dimers showed similar distributions of the marker particle relative to the main-view particle. The connection interfaces between the marker particle and the main-view $\mathrm{B}^{\text {act }}$ complex ranged from the upper part of the steep slope over the top center of the $\mathrm{B}^{\text {act }}$ complex to various parts of the shallow slope (Figs. 3A-D, 4A,B). No dimers were observed to be connected at the foot or at the bottom edges of the steep or the shallow slope. Applying our localization method described above, based on the $14 \mathrm{~nm}$ criterion, we found that the $\mathrm{C}$ termini of all the $\mathrm{U} 2 \mathrm{snRNP}$ proteins lie in the upper regions of the steep or the shallow slope. All areas touch the border of the main body of the $\mathrm{B}^{\text {act }}$ complex.

For the $\mathrm{C}$ terminus of Leal we found an area in the top corner of the steep slope at the border with the shallow slope

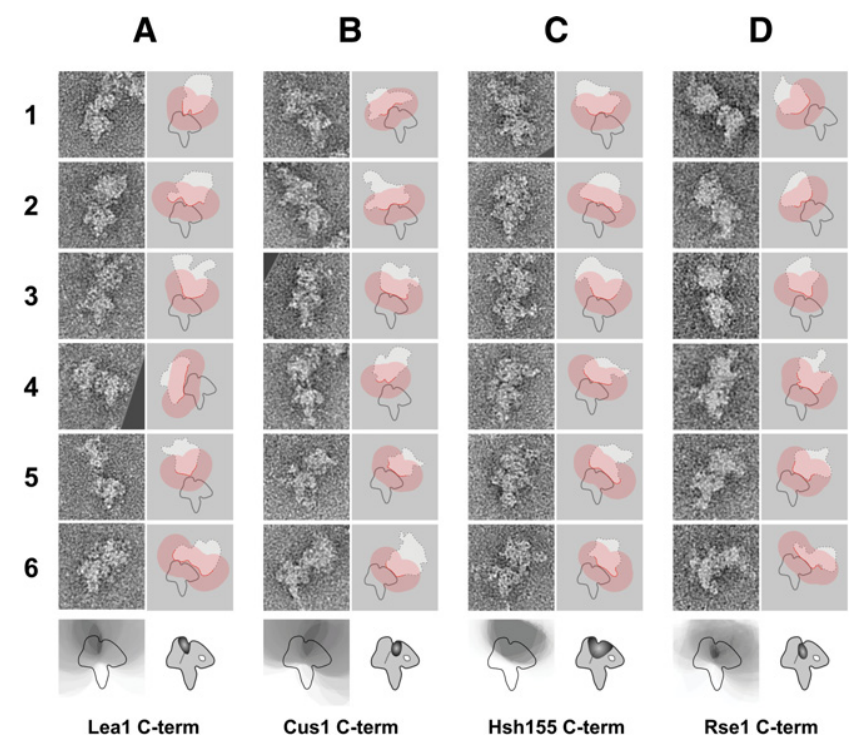

FIGURE 3. Locations of the U2 snRNP protein Leal and three SF3b proteins in the yeast spliceosomal $\mathrm{B}^{\text {act }}$ complex. EM images of $\mathrm{B}^{\text {act }}$ complex dimers were taken at 115,000 -fold magnification and analyzed as described in Figure 2. (A) C terminus of Leal. (B) C terminus of Cus1. (C) C terminus of Hsh155. (D) C terminus of Rse1. 
A

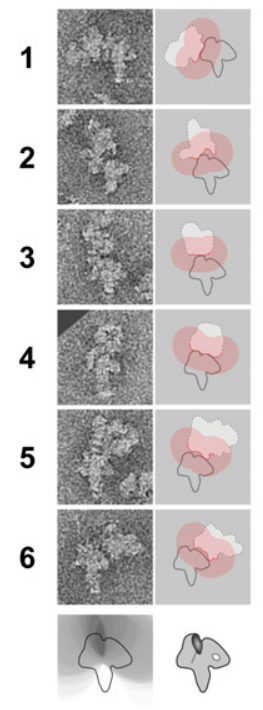

Prp9 C-term
B

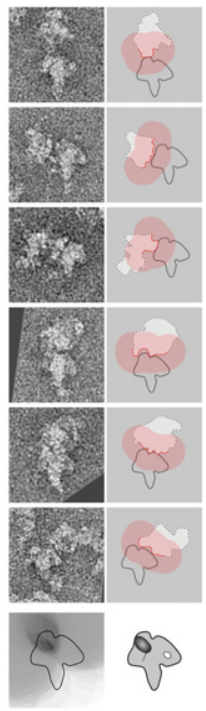

Prp11 C-term
C

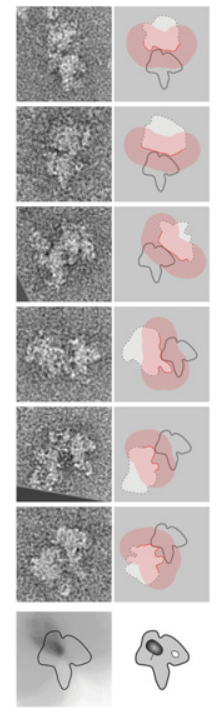

Pml1 C-term
D

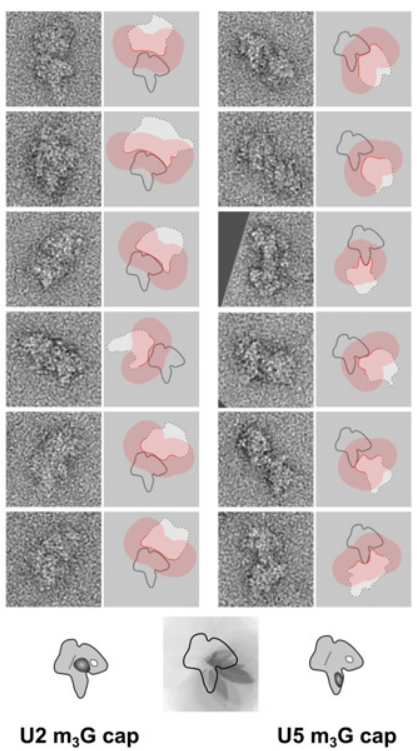

FIGURE 4. Locations of two SF3a proteins, the RES complex protein Pmll, and the $\mathrm{m}_{3} \mathrm{G}$ cap of $\mathrm{U} 2$ and $\mathrm{U} 5$ snRNAs. Proteins were located as described in Figure 2. For location of the $\mathrm{m}_{3} \mathrm{G}$ cap, two distinct areas within the $\mathrm{B}^{\text {act }}$ complex schematic drawing were generated after overlaying all dimers formed by an anti- $\mathrm{m}_{3} \mathrm{G}$ cap antibody and were assigned to $\mathrm{U} 2$ and $\mathrm{U} 5$, respectively. For each location, six representative dimers and corresponding schematic drawings are shown. $(A) \mathrm{C}$ terminus of Prp9. (B) C terminus of Prp11. (C) C terminus of Pml1. (D) $\mathrm{m}_{3} \mathrm{G}$ cap locations.

in immunoprecipitation experiments to interact with the SF3b complex (Wang et al. 2005). Attempts to locate the $C$ terminus of Snu17, which constitutes the core of the RES complex (Wysoczański et al. 2014), were not successful, since spliceosomal $\mathrm{B}^{\text {act }}$ complexes harboring Snu17-TAP did not dimerize upon addition of anti-TAP antibodies (Supplemental Fig. S2). Therefore, we located the C terminus of Pmll. Six representative dimers are shown in Figure 4C: the distribution of the marker particle resembles that of the U2 snRNP proteins in that dimerization mainly occurs through regions located at the top of the steep and the shallow slopes. In addition, we observed dimers where the marker particle was connected on the side of the foot proximal to the steep slope. The resulting position of the $\mathrm{C}$ terminus of Pmll, therefore, lies in the middle of the steep slope extending into the upper part of the main body (sketch in Fig. 4C) and colocalizes in part with the areas that we found for the U2 snRNP proteins.
(Fig. 3A), whereas the $\mathrm{C}$ terminus of Cus1 was located in the top third of the shallow slope, at the border with the steep slope (Fig. 3B). The area where the C terminus of Hsh155 is located lies in the upper regions of the steep and the shallow slopes, where both slopes are connected (Fig. 3C), overlapping in the shallow slope with the area where we found Cus1. The C terminus of Rsel is located in the upper central part of the $\mathrm{B}^{\text {act }}$ complex, exactly at the border of the steep and the shallow slope (Fig. 3D).

The area in which we found the $\mathrm{C}$ terminus of Prp9 occupies the upper end of the steep slope and the border with the shallow slope (Fig. 4A). We also located the C terminus of Prp 11 in the top half of the steep slope, an area directly below that of Prp9 and closer to the center of the $\mathrm{B}^{\text {act }}$ complex (Fig. 4B).

Taken together, the $\mathrm{C}$ termini of the SF3b complex proteins Rse 1 and Cus 1 reside in the top center of the $\mathrm{B}^{\text {act }}$ complex extending into the upper region of the shallow slope, whereas the $\mathrm{C}$ terminus of Hsh155 is located in the upper regions of both the steep and the shallow slopes. The $\mathrm{C}$ termini of Lea1 and the SF3a complex proteins Prp9 and Prp11 occupy areas in the top center of the particle and reach into the upper region of the steep slope.

\section{The RES complex colocalizes with the SF3b and SF3a proteins in the $\mathrm{B}^{\text {act }}$ complex}

The heterotrimeric RES complex is composed of Bud13, Snu17, and Pml1 (Dziembowski et al. 2004) and was found

\section{Location of the $5^{\prime}$ cap of the U2 and U5 snRNAs}

The U2 and U5 snRNAs contain a 2,2,7-trimthylguanosine $\left(\mathrm{m}_{3} \mathrm{G}\right)$ cap structure, which is not present in the U6 snRNA and the pre-mRNA. To locate the $5^{\prime}$ ends of the U2 and U5 snRNA molecules, we dimerized the $\mathrm{B}^{\text {act }}$ complexes by addition of a monoclonal anti- $\mathrm{m}_{3} \mathrm{G}$ antibody (H20) (Bochnig et al. 1987) and investigated the resulting dimers (Fig. 4D), as described above for TAP-tagged proteins. We found a distribution of the marker particle all around the main view of the $\mathrm{B}^{\text {act }}$ complex. When applying our localization method, based on the $14 \mathrm{~nm}$ criterion, to the data set obtained with the anti-cap antibody, we found two different areas of greatest overlap (sketch at the bottom of Fig. 4D), (all other labeling experiments yielded only a single area). One cap area lay in the right-hand two-thirds of the foot and one in the upper part of the main body. Knowing that the $\mathrm{U} 2$ snRNP proteins are located at top center in the $\mathrm{B}^{\text {act }}$ complex while the U5 snRNP proteins reach down to the foot, we assigned the area in the foot to the $5^{\prime}$ cap structure of the U5 snRNA and the area in the upper part of the main body to the cap structure of the U2 snRNA (Fig. 4D).

\section{NTC proteins are found in the central region and the steep slope of the $B^{\text {act }}$ complex}

One major building block of the $\mathrm{B}^{\text {act }}$ complex is the NTC (Supplemental Fig. S1). The NTC is thought to stabilize the 
rearranged RNA network of the spliceosome after the dissociation of the U4 snRNA and the U4/U6 proteins (Chan et al. 2003; Chan and Cheng 2005). To gain insight into the organization of the NTC in the spliceosome at the $\mathrm{B}^{\text {act }}$ stage, we located the C termini of five NTC proteins (Fig. 5). When the TAP tag was fused to the $C$ terminus of Prp19, we found spliceosome dimers in which the marker particle was connected to different regions of the steep slope, involving either the foot or the top end of the shallow slope (Fig. 5A). The resulting area where the $\mathrm{C}$ terminus of Prp19 is located lies in the middle of the steep slope and reaches into the main body (sketch in Fig. 5A).

A similar distribution of the marker particle was observed when $\mathrm{B}^{\text {act }}$ complexes harboring C-terminally tagged Syf1 were dimerized. In this case, however, dimerization did not occur at the foot (Fig. 5B). The final position of the C terminus of Syf1, therefore, lies in the upper part of the steep slope, at the border with the shallow slope (sketch in Fig. 5B). In the case of C-terminally tagged Isyl, the distribution of marker particles resembled that of Syf1, with additional dimers created by a connection of the marker particle at the lower half of the shallow slope (Fig. 5C). Thus, the final position of the $\mathrm{C}$ terminus of Isyl lies in the upper region of the shallow slope at the border with the steep slope (sketch at the bottom of Fig. 5C).

In the case of Cef1 the marker particles are distributed all around the main-view particle without any preferred side (Fig. 5D). Consequently, the resulting area where the $\mathrm{C}$ terminus of Cef1 could be located traverses the upper main body and overlaps with the area that we found for Prp19 (sketch in Fig. 5D).

A

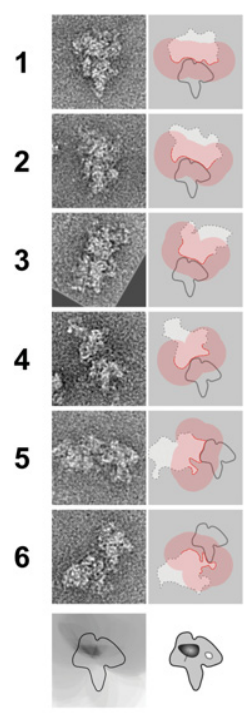

Prp19 C-term
B

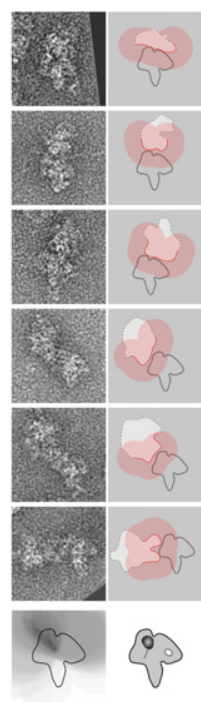

Syf1 C-term
C

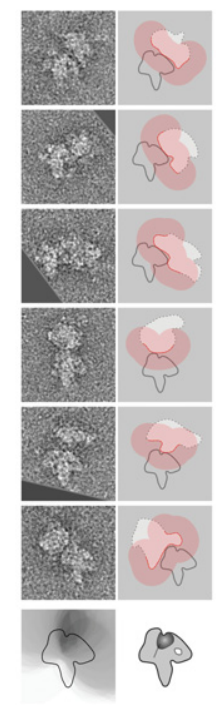

Isy1 C-term
D

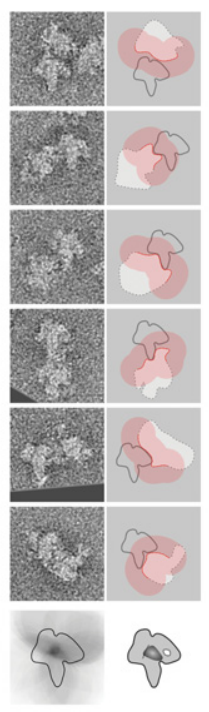

Cef1 C-term
In the case of Ntc20 we obtained a different distribution of the marker particle. All dimers showed a connection of the marker particle with the main-view particle at the bottom corner of the steep slope, in some cases involving the upper part of the steep slope or in other cases involving the foot (Fig. 5E). Our analysis for the position of the $\mathrm{C}$ terminus of Ntc20 resulted in an area that occupies the bottom corner of the steep slope (sketch in Fig. 5E).

Taken together, the NTC proteins are found in the upper central region of the $\mathrm{B}^{\text {act }}$ complex and in a large part of the steep slope.

\section{The $C$ termini of the $B^{\text {act }}$ proteins $\mathrm{Cwc2}$, Cwc21, and Cwc24 are located in the upper and central region of the B $^{\text {act }}$ complex}

The last large group of proteins that takes part in building the $\mathrm{B}^{\text {act }}$ complex is the set of the $\mathrm{B}^{\text {act }}$ proteins (Supplemental Fig. S1). We located the $\mathrm{C}$ termini of three proteins from this group: Cwc2, Cwc21, and Cwc24. Cwc2 was shown to be in contact with catalytically important RNA elements in the $\mathrm{B}^{\text {act }}$ complex, including regions of U6 and the pre-mRNA intron near the 5'SS and probably also the ISL of U6, thus placing Cwc2 at or near the spliceosome's catalytic center (McGrail et al. 2009; Rasche et al. 2012). When the TAP tag was fused to the $\mathrm{C}$ terminus of $\mathrm{Cwc} 2$, the resulting dimers showed connection of the marker particle at the bottom, the middle, or the top end of the steep slope (Fig. 6A). The resulting area where the $\mathrm{C}$ terminus of Cwc2 is located therefore lies in the middle of the steep slope, reaching into the top of the main body (sketch in Fig. 6A). In the case of C-terminally tagged Cwc21 we observed a distribution of marker particles all around the main-view particle (Fig. 6B), similar to the situation that we observed for the $\mathrm{N}$ terminus of Prp8 and the $\mathrm{C}$ terminus of Cef1. Thus the C terminus of Cwc21 is located in an area at the center of the main body (sketch in Fig. 6B).

Next we located Cwc24, which was shown to be required for step 1 but not for catalysis per se (Warkocki et al. 2009; Ohrt et al. 2012). C-terminally tagged Cwc24 treated with anti-TAP antibodies gave dimers in which the connection of the marker particle with the main-view dimer was seen at the top center of the $\mathrm{B}^{\text {act }}$ complex, in the middle of the shallow slope, or at its bottom corner (Fig. 6C). This distribution implied a final area for the location of Cwc24's Cterminal part as being in the top half of the shallow slope, where it is connected to the main body (sketch in Fig. 6C), overlapping on the one side with the
FIGURE 5. Locations of NTC complex proteins in the yeast spliceosomal $\mathrm{B}^{\text {act }}$ complex. EM images of $B^{\text {act }}$ complex dimers were analyzed as described in Figure $2(A) C$ terminus of Prp 19. $(B) C$ terminus of Syf1. (C) C terminus of Isyl. (D) C terminus of Cef1. (E) C terminus of Ntc20. 
A

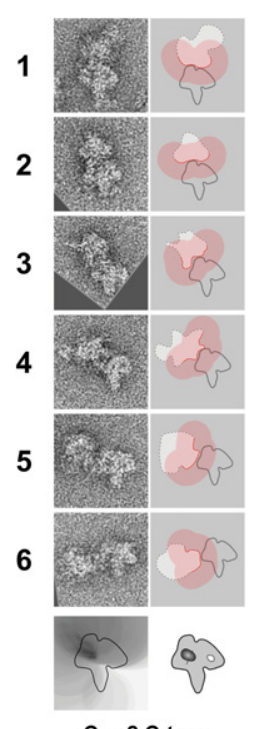

Cwc2 C-term
B

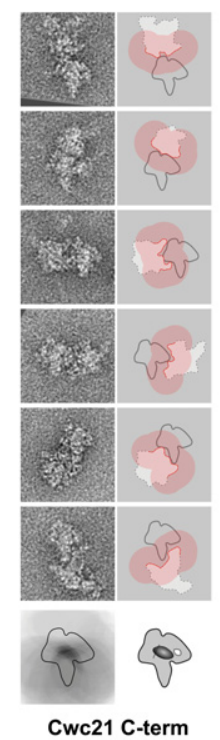

C

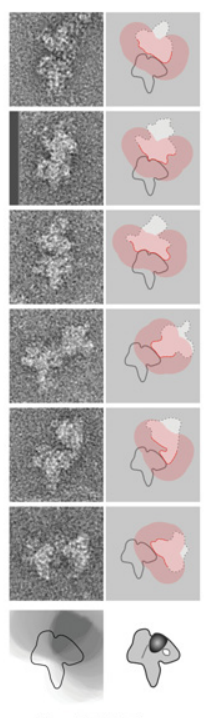

Cwc24 C-term
D

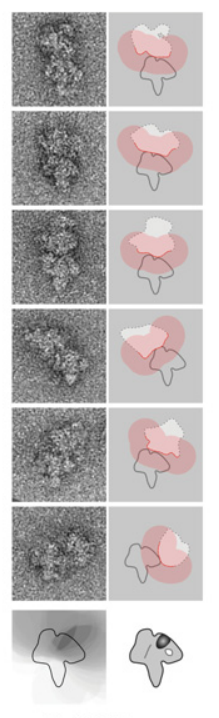

Prp2 C-term

FIGURE 6. Locations of $\mathrm{B}^{\text {act }}$ proteins and Prp2 and Spp2 in the yeast spliceosomal $\mathrm{B}^{\text {act }}$ complex. EM images of $B^{\text {act }}$ complex dimers were analyzed as described in Figure $2(A) C$ terminus of Cwc2. (B) C terminus of Cwc21. (C) C terminus of Cwc24. (D) C terminus of Prp2. (E) N terminus of Spp2.

area where we found Hsh155 and on the other with the area where we found the $\mathrm{C}$ terminus of Prp8.

\section{Prp2 and Spp2 are found in the upper central region of the $B^{\text {act }}$ complex}

Catalytic activation of the spliceosome and the formation of the catalytically active $\mathrm{B}^{*}$ complex requires the DEAH-box NTPase Prp2 and its cofactor Spp2 (Warkocki et al. 2009, 2015). The action of the RNA helicase Prp2 depends on its interaction with Spp2 and the pre-mRNA intron at nucleotides downstream from the BPS (Liu and Cheng 2012). To determine where these two proteins are situated in the $\mathrm{B}^{\text {act }}$ complex, we assembled $\mathrm{B}^{\text {act }}$ complexes on the truncated Actin $\Delta 6$ pre-mRNA construct and located on them the $\mathrm{C}$ terminus of Prp2 and the $\mathrm{N}$ terminus of Spp2. $\mathrm{B}^{\text {act }}$ complexes stalled by using heat-inactivated extract derived from a yeast strain harboring the prp2-1 mutation do not contain Prp2 or Spp2 (Warkocki et al. 2009) and therefore could not be used. The Actin $\Delta 6$ construct allows efficient activation of the spliceosome (i.e., $\mathrm{B}^{\text {act }}$ complex formation) but does not allow catalytic activation or the subsequent catalysis of step 1 of splicing (Cheng 1994; Fabrizio et al. 2009). Addition of the anti-TAP antibody to complexes harboring C-terminally tagged Prp2 led to dimers that showed a distribution of the marker particle similar to that observed for Cwc24, with a connection occurring either at the shallow slope or in the upper corner of the steep slope, in some cases involving the top edge of the steep slope (Fig. 6D). The final area where the $\mathrm{C}$ terminus of Prp2 was located is shown schematically

E

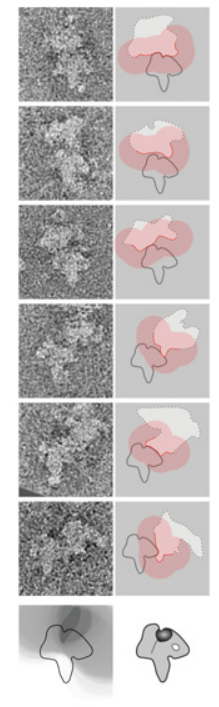

Spp2 N-term in Figure 6D and can be found in the top third of the shallow slope. An almost identical distribution of the marker particle was observed when the TAP tag was fused to the $\mathrm{N}$ terminus of Spp2 (Fig. $6 \mathrm{E})$. Thus, the resulting area where the $\mathrm{N}$ terminus of Spp2 is located overlaps with that of Prp2 in the top end of the shallow slope and reaches the border with the steep slope (sketch in Fig. 6E).

\section{DISCUSSION}

We investigated the positions of twenty protein termini and two RNA molecules representing each building block of the spliceosomal $\mathrm{B}^{\text {act }}$ complex by locating their $\mathrm{C}$ or $\mathrm{N}$ terminus or $5^{\prime}$ end, respectively, using a negative-stain EMbased immunolocation method developed previously (Rigo et al. 2015). As summarized in Figure 7, these protein locations provide insight into the structural organization of the yeast spliceosomal $\mathrm{B}^{\text {act }}$ complex.

\section{Brr2 performs a significant movement upon activation of the spliceosome}

Brr2, Prp8, Snu114, and the U5 snRNA (together with its Sm ring and the U6 snRNA molecule) are the only components of the tri-snRNP that remain bound to the spliceosome after activation (Fabrizio et al. 2009). In the $\mathrm{B}^{\text {act }}$ complex we located the $5^{\prime}$ end of the U5 snRNA, the C terminus of Snu114, and the $\mathrm{N}$ and $\mathrm{C}$ termini of Brr2 and Prp8. We found that the $\mathrm{N}$ terminus of Brr2 and the $\mathrm{C}$ termini of Prp8 and Snu114 are lined up in the main body. Together with the position of the U5 RNA $5^{\prime}$ cap in the foot region, this arrangement resembles the U5 axis as previously identified by labeling of the yeast B complex (Rigo et al. 2015). At the yeast tri-snRNP, a similar U5 axis was earlier inferred by EM labeling experiments (Häcker et al. 2008); more recently, its structure was determined at high resolution by cryo-EM 3D reconstruction (Nguyen et al. 2016a; Wan et al. 2016). These findings establish the architecture of the U5 axis of the tri-snRNP with the U5 Sm ring at the lower foot and the U5 $5^{\prime}$ cap close by and just above these, Snu114 including its $\mathrm{C}$ terminus, followed by the large Prp8 N-terminal and central RT/En domains. This architecture appears to be present in the $\mathrm{B}^{\text {act }}$ complex as well, since it is highly consistent with our labeling results. Indeed, a similar architecture was also found in a later stage of the spliceosome cycle by cryoEM reconstruction of the S. pombe ILS (Yan et al. 2015). This axis appears to be a central docking domain of the spliceosome. 
A

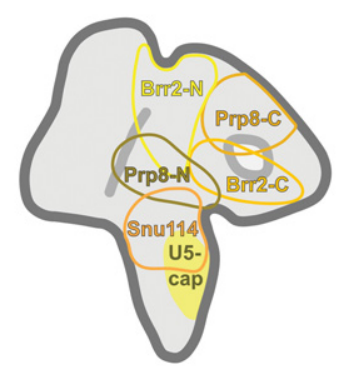

B

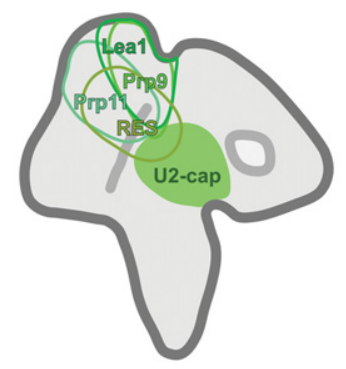

C

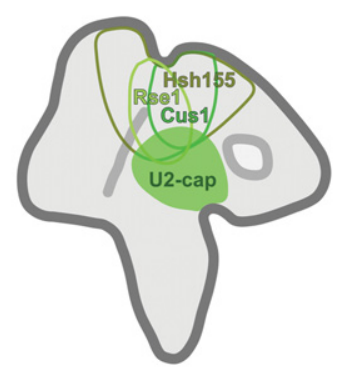

D

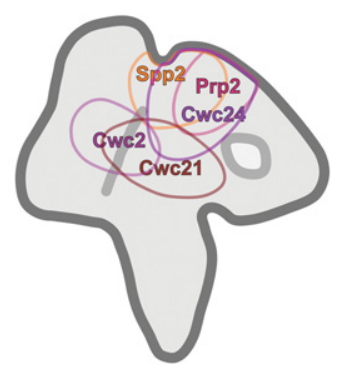

E

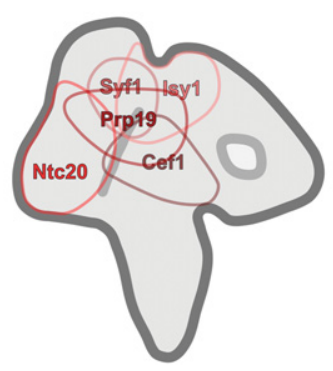

$\mathbf{F}$

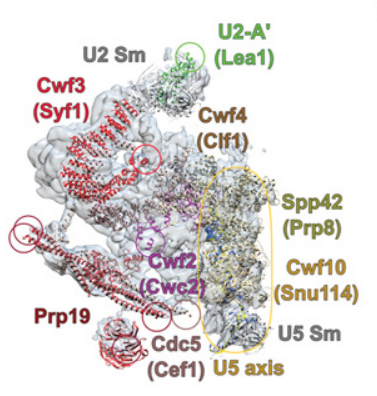

G

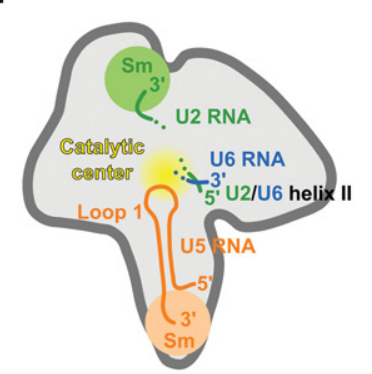

FIGURE 7. Summary of the protein positions and proposed location of the catalytic center of the $\mathrm{B}^{\text {act }}$ complex from S. cerevisiae. Protein locations are shown as outlined areas with distinct colors. Cap locations and deduced locations of Sm sites and the catalytic center are shown as filled areas in distinct colors. (A) Locations of U5 snRNP proteins and the $5^{\prime}$ cap of U5. (B) Locations of the U2 snRNP protein Lea1, two SF3a proteins, the RES complex, and the $5^{\prime}$ cap of U2 snRNA. (C) Locations of three SF3b proteins, together with the $5^{\prime}$ cap of U2 snRNA. $(D)$ Locations of $B^{\text {act }}$ proteins and Prp2/Spp2. (E) Locations of five NTC proteins. $(F)$ SnRNP and non-snRNP proteins in the S. pombe ILS spliceosome which are shared with S. cerevisiae $\mathrm{B}^{\text {act }}$ complex. Circles mark the $\mathrm{C}$ termini of the corresponding proteins. The vertical area outlined with a yellow oval indicates the U5 snRNP. (G) Summary of the deduced locations of crucial RNA elements of U2 (green), U6 (blue), and U5 (orange) snRNAs and the position of the catalytic center (yellow) in the $\mathrm{B}^{\text {act }}$ complex deduced from the results of this work.

However, the position of Brr2 in the $\mathrm{B}^{\text {act }}$ complex differs significantly when compared with that in the yeast trisnRNP as well as that of the B complex. In the cryo-EM structure of the yeast tri-snRNP, the Brr2 tandem helicase cassettes continue the U5 axis with the C-terminal cassette at the top end. A Brr2 arrangement such as that in the yeast tri-snRNP is also present in the $\mathrm{B}$ complex, since the $\mathrm{C}$ terminus of Brr2 was located by EM-labeling at the top end of its U5 axis, a location very similar to that of the labeling position in the yeast tri-snRNP (Häcker et al. 2008; Rigo et al. 2015). The long U5 axis of the yeast tri-snRNP and the corresponding axis in the B complex are also very similar in their appearance (Häcker et al. 2008; Rigo et al. 2015). In the yeast $B^{\text {act }}$ complex we have now found the Brr2 helicase cassettes in a different orientation relative to the canonical U5 axis: Brr2's C terminus, which is placed directly at the outer end of the C-terminal cassette, is found at the bottom of the shallow slope and points downward rather than upward. As the position of Prp8's C terminus in the upper shallow slope region marks the position of Brr2's N-terminal cassette (Prp8's C-terminal Jab1 domain binds tightly to Brr2's N-terminal cassette [Mozaffari-Jovin et al. 2013; Nguyen et al. 2013]), the tandem helicase is obviously positioned in the shallow slope with the C-terminal cassette tilted downward. This ob- servation defines a substantial structural change during the transition from the $\mathrm{B}$ to the $\mathrm{B}^{\text {act }}$ complex and may be a consequence of Brr2's helicase activity that unwinds the U4/U6 duplex.

\section{The U2 snRNP and the RNA helicase Prp2 are located in the upper regions of the $B^{\text {act }}$ complex}

The positions of the $\mathrm{U} 2$ proteins investigated in this work are summarized in Figure 7B and C, which show that they all are located in the upper central region of the $\mathrm{B}^{\text {act }}$ complex, indicating that the $\mathrm{U} 2$ snRNP remains a compact entity in the $\mathrm{B}^{\text {act }}$ complex. By comparing the U5 snRNP protein positions (Fig. 7A) with the positions of the U2 snRNP proteins (Fig. $7 \mathrm{~B}, \mathrm{C})$, it can be seen that the $\mathrm{N}$ terminus of Brr2 and its $\mathrm{N}$-terminal helicase cassette (area where the $\mathrm{C}$ terminus of Prp8 is located) overlap with Cus1 in the upper region of the main body and at the top of the shallow slope, respectively. Although overlapping areas in 2D projections might not necessarily reflect a colocalization in 3D space, here proximity does seem possible, and indeed binding between human U5 and U2 snRNP proteins has been found by a yeast twohybrid screen and a coimmunoprecipitation study (Hegele et al. 2012). Among other proteins, Cus1 and Brr2 have 
been found to interact with each other. The position of Leal indicates the region where the U2 Sm ring is located, as it binds together with Msl1, to a U2 snRNA stem-loop downstream from the Sm binding site (Price et al. 1998).

During catalytic activation of the spliceosome (from $\mathrm{B}^{\text {act }}$ to $\mathrm{B}^{*}$ ), the BP adenosine has to be exposed and freed from SF3a and SF3b proteins before the first catalytic step of splicing can take place, which is achieved by the action of the DEAH-box helicase Prp2 together with its cofactor Spp2 (Warkocki et al. 2009; Lardelli et al. 2010; Liu and Cheng 2012). Prp2 requires Spp2 for activating the spliceosome, which is consistent with our finding that the areas where we found these two proteins overlap in the $\mathrm{B}^{\text {act }}$ complex (summarized in Fig. 7D). Prp2 binds to the pre-mRNA downstream from the BP (Liu and Cheng 2012) in a region where Hsh155 and the RES complex could be cross-linked to the intron (Schneider et al. 2015). These observations make it seem very likely that the overlapping areas_or close proximities_of Prp2, Spp2, Pml1, and Hsh155 reflect real physical proximity of these proteins. The respective termini are probably positioned on the same side (front or back) of the particle.

\section{NTC proteins reside in or close to the steep slope}

Besides the U2 and U5 snRNPs, one major building block of the $\mathrm{B}^{\text {act }}$ complex is the NTC, which stabilizes the newly formed, catalytically active RNA network made up of the U2, U6, and U5 snRNAs (Hogg et al. 2010). To locate the NTC and gain insight into the global architecture of the $\mathrm{B}^{\text {act }}$ complex, we located five of the 10 NTC core proteins: Prp19, Syf1, Cef1, Isy1, and Ntc20.

In the recent cryo-EM 3D reconstruction of the S. pombe ILS (Yan et al. 2015), several NTC proteins are modeled within the complex; therefore we compared the location of NTC proteins in our $\mathrm{B}^{\text {act }}$ with this ILS complex. For Syf1 (Cwf3 in S. pombe) in the ILS, the N-terminal part of its TPR repeats starts above Cwc2 (Cwf2) and the C-terminal part approaches the RT domain side of Prp8 (Spp42). Our localization of the $\mathrm{C}$ terminus of Syf1 in the $\mathrm{B}^{\text {act }}$ complex fits in well with a TPR arrangement, as seen in the ILS. As we found Cwc2 at the interface between the U5 axis and the steep slope, which would mark the N-repeats, the TPRs could pass through the $\mathrm{B}^{\text {act }}$ complex within the steep slope and end at the Syf1 C terminus position in the upper part of the steep slope. At the lower tip region of the steep slope we located the $\mathrm{C}$ terminus of the small protein $\mathrm{Ntc20}$, which is present only in S. cerevisiae spliceosomes. Its location fits in well with the assignment of the steep slope as being the domain of the $\mathrm{B}^{\text {act }}$ complex that contains the NTC proteins. When orienting the ILS structure with the U5 axis pointing straight up (with U5 Sm at the bottom) and with Syf1 and Clf1 (Cwf4) protruding sideward (Fig. 7F), the Cwc2 protein becomes positioned between the U5 axis and the Syf1/Clf1 proteins, reflecting exactly the topology of the positions at which the $\mathrm{B}^{\text {act }}$ complex was labeled.
Two other important NTC proteins that we have located are Prp19 and Cef1 (Cdc5). The Prp19 protein consists of an N-terminal ubiquitin ligase U-box domain, a $10-\mathrm{nm}$ long a helix, and a WD40 domain at its $\mathrm{C}$ terminus; four copies of it are present in the NTC complex and the spliceosomes. The helices from two copies form a long parallelarranged coiled coil (Fig. 7F). The two pairs are joined at their $\mathrm{N}$ termini, so that a $20-\mathrm{nm}$-long rod-like structure with the C termini at its ends is created (Yan et al. 2015). In the ILS structure this rod-like structure runs diagonally from the central, upper region where Syf1's and Clf1's TPRs are located to the lower foot region containing the U5 Sm ring. The C terminus of Cef1 (Cdc5) is located at its lowest position. In the $\mathrm{B}^{\text {act }}$ complex we found Cef1's $\mathrm{C}$ terminus and the $\mathrm{C}$ termini of Prp19 further up at the main body, in part reaching into the steep slope, indicating a different arrangement of the Prp19/Cef1 rod-like structure at the $\mathrm{B}^{\text {act }}$ spliceosomal stage.

\section{Direct and indirect localization of RNA elements reveal the position of the catalytic center in the $B^{\text {act }}$ complex}

We found the $5^{\prime}$ ends of the U2 and U5 snRNAs directly by locating their $\mathrm{m}_{3} \mathrm{G}$ cap structures. Furthermore, we were able to deduce indirectly the positions of certain RNA elements that have been shown to interact with the proteins that we located in the $\mathrm{B}^{\text {act }}$ complex. The positions of important RNA elements, as deduced from our localization experiments, are shown in Figure 7G. Lea1 is the yeast homolog of the human $\mathrm{U}^{2}-\mathrm{A}^{\prime}$, which has been shown to form a complex with U2- $\mathrm{B}^{\prime \prime}$ (the human ortholog of Msl1) and with loop IV at the $3^{\prime}$ end of the U2 snRNA (Price et al. 1998). Thus, from the position of Leal we can indirectly determine the positions of loop IV and the Sm ring of the U2 snRNA. Lea1, and therefore the $3^{\prime}$ end and the Sm ring of the U2 snRNA, lie in the upper region of the steep slope, where it connects to the shallow slope (Fig. 7G).

From the position of Cwc2, which could previously be cross-linked to the U6 ISL and to the pre-mRNA close to the 5'SS (McGrail et al. 2009; Rasche et al. 2012) and was located here in the middle of the steep slope, reaching into the upper half of the main body, we can conclude that the U6 ISL and the $5^{\prime} \mathrm{SS}$ are located in the middle and upper region of the main body (Fig. 7G).

In addition to these indirect localizations of RNA molecules, we also directly located the $5^{\prime}$ end of the U2 snRNA, which is positioned in the center of the main body of the $\mathrm{B}^{\text {act }}$ complex (Fig. 7B). The $5^{\prime}$ end of the U2 snRNA base pairs with the $3^{\prime}$ end of the U6 snRNA to form helix II and the U2 snRNA sequence $3^{\prime}$ of helix II is involved in forming the helices Ia and Ib with the U6 snRNA which are part of the catalytically active RNA network (Madhani and Guthrie 1994; Hilliker and Staley 2004; Mefford and Staley 2009).

We further located the $5^{\prime}$ end of the U5 snRNA in the right half of the foot (Fig. 7A). The U5 axis extends from the bottom tip of the foot to the center of the main body and is made 
up of the Sm core, Snu114, and Prp8. As discussed above, it is feasible to conclude that the $3 \mathrm{D}$ organization of the U5 axis is preserved in the $\mathrm{B}^{\text {act }}$ complex as well. On the basis of this assumption, we were able to place the active-site cavity of Prp8 (Galej et al. 2013; Nguyen et al. 2015) and the U5 snRNA loop I that is close to the 5'SS (McConnell and Steitz 2001) in the center of the main body of the $\mathrm{B}^{\text {act }}$ complex.

Taken together, direct and indirect RNA localizations place the U2/U6 helices Ia, Ib, and II in the center of the main body where the U6 ISL-and most probably also the 5'SS-reside (Fig. 7G). From all these inferred RNA positions we can conclude that the catalytically important U2/U6/U5/ pre-mRNA network, and thus the catalytic center of the spliceosome, lie in the center of the main body of the $\mathrm{B}^{\text {act }}$ complex (Fig. 7G).

From the locations of the SF3b complex proteins Hsh155, Cus1, and Rse1, we determined that the SF3b complex lies in the upper one-third of the $\mathrm{B}^{\text {act }}$ complex, ranging from the upper region of the shallow slope to the top part of the steep slope. The area where we located the SF3a proteins Prp9 and Prp11 overlaps with the position of the SF3b complex but does not extend to the shallow slope (Fig. 7B). The SF3a complex is positioned in the upper half of the steep slope of the $\mathrm{B}^{\text {act }}$ complex. Various nucleotides of the pre-mRNA intron around the BPS region, as well as downstream from the BP up to the 3'SS, have been cross-linked to Hsh155 (Schneider et al. 2015). In the same study, pre-mRNA nucleotides upstream of the BPS were found to cross-link to Cus1, Prp9, and Prp11 in the $B^{\text {act }}$ complex and nucleotides at the $3^{\prime}$ end of the intron have been found to cross-link to RES complex proteins (discussed above). From these protein locations we can conclude that the U2/pre-mRNA BP helix must be located close to, perhaps a bit upward, of the center of the main body, where we placed the emerging catalytic center of the $\mathrm{B}^{\text {act }}$ complex.

\section{MATERIALS AND METHODS}

\section{Strains and plasmids}

Yeast strains expressing the respective C- or N-terminally TAPtagged proteins had either been constructed previously (Häcker et al. 2008; Rigo et al. 2015) or were produced in this work according to the method described earlier (Puig et al 2001); they are listed in Supplemental Table S1. Four parental strains are used in this work, including TR2 (Mat a, trp1- $\Delta 1$, his3- $\Delta$, ura3-52, lys2-801, ade2-101); YPH499 (Mat a, ura3-52, lys2-801, ade2-101, trp1- $\Delta 63$,

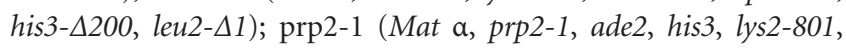
ura3, carrying a G360D substitution in the helicase domain of Prp2); and BJ2168 (Mat a, gal2, leu2, pep4-3, prc1-407, prb1-1122, trp1, ura3-52). The yeast strains expressing the respective C-terminally TAP-tagged proteins obtained from Euroscarf were tagged in the parental strain (Mat a, ade2, arg4, leu2-3, 2-112, trp1-289, ura3-52). Plasmid pBS1479 (Puig et al. 2001) was used as a template to amplify the C-terminal TAP cassette and then fused to the $\mathrm{C}$ terminus of the respective protein by PCR. Plasmid pBS1761 (Puig et al. 2001) was used for constructing the N-terminally TAP-tagged proteins mainly as described in Puig et al. (2001). In some cases the TEV protease cleavage site of the TAP tag was replaced by a PreScission protease cleavage site. In those cases the plasmid pBS1539-Psc (Kramer et al. 2014) was used as PCR template. No differences were found in the growth of the TAP-tagged strains as compared to their untagged parental strains, as previously described (Rigo et al. 2015).

\section{Purification and immunolabeling of spliceosomal $B^{\text {act }}$ complexes}

Spliceosomal B ${ }^{\text {act }}$ complexes were assembled and purified according to the methods described previously (Fabrizio et al. 2009; Warkocki et al. 2009; Rigo et al. 2015). Uniformly [ $\left.{ }^{32} \mathrm{P}\right]$-labeled M3-Actin wild-type or M3-Actin $\Delta 6$ pre-mRNAs, retaining $6 \mathrm{nt}$ downstream from the BS, were produced by transcription in vitro with T7 RNA polymerase and preincubated with a 15 -fold molar excess of the MS2-MBP fusion protein in $20 \mathrm{mM} \mathrm{HEPES} \mathrm{(} \mathrm{pH} 7.9$ ) at $4^{\circ} \mathrm{C}$ for $30 \mathrm{~min}$. The MS2-MBP-bound pre-mRNA was then incubated for $60 \mathrm{~min}$ with yeast whole-cell extract under splicing conditions (60 mM K $\mathrm{HPO}_{4} / \mathrm{KH}_{2} \mathrm{PO}_{4} \mathrm{pH} 7.4 ; 3 \% \mathrm{w} / \mathrm{v}$ PEG-8000; $2 \mathrm{mM}$ ATP; $2 \mathrm{mM}$ spermidine; $2.5 \mathrm{mM} \mathrm{MgCl}_{2} ; 40 \% \mathrm{v} / \mathrm{v}$ yeast extract; $2 \mathrm{nM}$ pre-mRNA at $30-50 \mathrm{cpm} / \mathrm{fmol})$. After complex assembly, the potassium concentration was adjusted to $150 \mathrm{mM}$ and the precipitate was removed by centrifugation for $10 \mathrm{~min}$ at $13,300 \mathrm{~g}$ and $4^{\circ} \mathrm{C}$. The supernatant was loaded onto amylose-agarose (New England Biolabs) pre-equilibrated in G150 buffer (20 mM HEPES-KOH pH 7.9; $1.5 \mathrm{mM} \mathrm{MgCl}_{2} ; 150 \mathrm{mM} \mathrm{KCl} ; 0.5 \mathrm{mM} \mathrm{DTT} ; 0.5 \mathrm{mM}$ PMSF) containing 5\% w/v glycerol and $0.01 \% \mathrm{w} / \mathrm{v}$ NP-40. After washing with $10 \mathrm{~mL}$ of G150 buffer and $50 \mathrm{~mL}$ of G75 buffer (20 mM HEPES-KOH pH 7.9; $1.5 \mathrm{mM} \mathrm{MgCl}_{2} ; 75 \mathrm{mM} \mathrm{KCl}$; $0.5 \mathrm{mM}$ DTT; $0.5 \mathrm{mM}$ PMSF) containing 5\% w/v glycerol and $0.01 \% \mathrm{w} / \mathrm{v}$ NP- $40, \mathrm{~B}^{\text {act }}$ complexes were eluted with $12 \mathrm{mM}$ maltose in G75 buffer containing 5\% w/v glycerol and $0.01 \% \mathrm{w} / \mathrm{v}$ NP-40. From the peak fractions, 4-14 pmol of $\mathrm{B}^{\text {act }}$ complexes were taken and incubated for $90 \mathrm{~min}$ on ice with rabbit polyclonal anti-TAP antibodies (Thermo Fischer Scientific) in a molar ratio from 1:1 to 1:4. For cap localization, instead of anti-TAP antibody, mouse monoclonal anti-cap antibody (H20; Bochnig et al. 1987) was used. The control was incubated for 90 min on ice but without antibodies. After antibody binding, the whole volume was loaded onto a $10 \%-30 \%$ w/v glycerol gradient with $0 \%-0.04 \%$ or $0 \%-0.1 \%$ w/v glutaraldehyde (Electron Microscopy Sciences) gradient in G75 buffer and centrifuged at $4^{\circ} \mathrm{C}$ in a Sorvall TH660 rotor for $16 \mathrm{~h}$ at 51,000g (max.). The gradients were harvested from the bottom in $125 \mu \mathrm{L}$ fractions. The peak fractions were used directly for EM specimen preparation. To confirm the presence of the antibody in the gradient fractions, ELISA was carried out essentially as described by Wolf et al. (2009). To obtain a better ELISA signal, we also used the PAP complex (peroxidase-anti-peroxidase complex) (Sigma-Aldrich) in addition to anti-TAP antibodies in the cases of Hsh155, Rse1, and Spp2. The gradient profiles and ELISA results were drawn with the software Graphpad Prism (Graphpad Software Inc.).

\section{Electron microscopy and image processing}

Negative-stain EM grid preparation and image processing were carried out essentially as described previously (Rigo et al. 2015). For 
grid preparation, $\sim 25 \mu \mathrm{L}$ of the peak gradient fraction was first quenched with $50 \mathrm{mM}$ glycine and then pipetted into a well in a polyoxymethylene block precooled on ice. The sample was then covered with a thin $(<10 \mathrm{~nm})$ carbon film and a perforated carbon copper mesh grid. Particles in the sample were allowed to adsorb onto the carbon film for typically $120-180 \mathrm{~min}$. The adsorbed particles were then transferred to another well on the polyoxymethylene block containing $2.5 \% \mathrm{w} / \mathrm{v}$ uranyl formate (in $\mathrm{ddH}_{2} \mathrm{O}$ ) and stained for $2.5 \mathrm{~min}$ on ice. After staining, grids were dried at room temperature for $\sim 10 \mathrm{~min}$ and stored until image acquisition. EM images were taken in a CM200 FEG microscope (FEI) with $160 \mathrm{kV}$ acceleration voltage in eucentric height and a defocus of $\sim 1.2 \mu \mathrm{m}$ using a $4 \mathrm{k} \times 4 \mathrm{k}$ CCD camera (TVIPS) with twofold binning of the pixels. Images were taken at a magnification of 80,000 for class averages and 115,000 for protein localization analysis. For class averages, $\sim 12,800$ single-particle images of Cwc2 TAP-tagged monomeric yeast $\mathrm{B}^{\text {act }}$ complexes were collected and image processing was performed according to Rigo et al. (2015). For locating proteins, complex dimers of each tagged protein in which the morphology of the main-view particle were clearly recognized, were collected from raw images and used for mapping the location of the tagged protein in the $\mathrm{B}^{\text {act }}$ complex on the basis of the procedure described in the main text.

For Brr2-TAP, Prp8-TAP, Snu114-TAP, and Prp2-TAP, to rule out bias, the collection of the dimer images was carried out independently by two different persons, yielding two partly overlapping data sets for each protein. Analysis of each data set was performed independently by three different persons and yielded a largely identical localization result for each respective protein. For Cwc2-TAP, two independent labeling experiments applying the same method were performed, resulting in two independent data sets. Independent analysis of these two data sets by three persons yielded the same localization result. The agreement between the results of these parallel, independent analyses supports the claim that our method is adequately objective.

\section{SUPPLEMENTAL MATERIAL}

Supplemental material is available for this article.

\section{ACKNOWLEDGMENTS}

We thank T. Conrad for large-scale yeast fermentation, E. Penka and W. Behrens-Kranz for technical assistance, I. Häcker, K-L. Boon, C. Schneider, and O. Dybkov for creating the yeast strains, E. Tonevitsky and N. Rasche for biochemical and EM experiments in the initial phase of the project, and $\mathrm{H}$. Stark for providing EM infrastructure. This work was funded by a grant from the Deutsche Forschungsgemeinschaft (SFB860).

Received May 16, 2016; accepted May 31, 2016.

\section{REFERENCES}

Agafonov DE, Kastner B, Dybkov O, Hofele RV, Liu WT, Urlaub H, Lührmann R, Stark H. 2016. Molecular architecture of the human U4/U6.U5 tri-snRNP. Science 351: 1416-1420.

Bessonov S, Anokhina M, Krasauskas A, Golas MM, Sander B, Will CL, Urlaub H, Stark H, Lührmann R. 2010. Characterization of purified human $\mathrm{B}^{\text {act }}$ spliceosomal complexes reveals compositional and morphological changes during spliceosome activation and first step catalysis. RNA 16: 2384-2403.

Bochnig P, Reuter R, Bringmann P, Lührmann R. 1987. A monoclonal antibody against 2,2,7-trimethylguanosine that reacts with intact, class $\mathrm{U}$, small nuclear ribonucleoproteins as well as with 7-methylguanosine-capped RNAs. Eur J Biochem 168: 461-467.

Branlant C, Krol A, Ebel JP, Lazar E, Haendler B, Jacob M. 1982. U2 RNA shares a structural domain with U1, U4, and U5 RNAs. EMBO J 1: 1259-1265.

Busch H, Reddy R, Rothblum L, Choi YC. 1982. SnRNAs, SnRNPs, and RNA processing. Annu Rev Biochem 51: 617-654.

Caspary F, Séraphin B. 1998. The yeast U2A'/U2B complex is required for pre-spliceosome formation. EMBO J 17: 6348-6358.

Chan SP, Cheng SC. 2005. The Prp19-associated complex is required for specifying interactions of U5 and U6 with pre-mRNA during spliceosome activation. J Biol Chem 280: 31190-31199.

Chan SP, Kao DI, Tsai WY, Cheng SC. 2003. The Prp19p-associated complex in spliceosome activation. Science 302: 279-282.

Cheng SC. 1994. Formation of the yeast splicing complex A1 and association of the splicing factor PRP19 with the pre-mRNA are independent of the $3^{\prime}$ region of the intron. Nucleic Acids Res 22: 1548-1554.

Chiu YF, Liu YC, Chiang TW, Yeh TC, Tseng CK, Wu NY, Cheng SC. 2009. Cwc25 is a novel splicing factor required after Prp2 and Yju2 to facilitate the first catalytic reaction. Mol Cell Biol 29: 5671-5678.

Cordin O, Beggs JD. 2013. RNA helicases in splicing. RNA Biol 10: 83-95.

Cordin O, Hahn D, Beggs JD. 2012. Structure, function and regulation of spliceosomal RNA helicases. Curr Opin Cell Biol 24: 431-438.

Datta B, Weiner AM. 1991. Genetic evidence for base pairing between U2 and U6 snRNA in mammalian mRNA splicing. Nature 352: 821-824.

Dziembowski A, Ventura AP, Rutz B, Caspary F, Faux C, Halgand F, Laprévote O, Séraphin B. 2004. Proteomic analysis identifies a new complex required for nuclear pre-mRNA retention and splicing. EMBO J 23: 4847-4856.

Fabrizio P, Dannenberg J, Dube P, Kastner B, Stark H, Urlaub H, Lührmann R. 2009. The evolutionarily conserved core design of the catalytic activation step of the yeast spliceosome. Mol Cell 36: 593-608.

Fica SM, Mefford MA, Piccirilli JA, Staley JP. 2014. Evidence for a group II intron-like catalytic triplex in the spliceosome. Nat Struct Mol Biol 21: 464-471.

Galej WP, Oubridge C, Newman AJ, Nagai K. 2013. Crystal structure of Prp8 reveals active site cavity of the spliceosome. Nature 493: 638-643.

Golas MM, Sander B, Bessonov S, Grote M, Wolf E, Kastner B, Stark H, Lührmann R. 2010. 3D cryo-EM structure of an active step I spliceosome and localization of its catalytic core. Mol Cell 40: 927-938.

Gozani O, Feld R, Reed R. 1996. Evidence that sequence-independent binding of highly conserved U2 snRNP proteins upstream of the branch site is required for assembly of spliceosomal complex A. Genes Dev 10: 233-243.

Grainger RJ, Barrass JD, Jacquier A, Rain JC, Beggs JD. 2009. Physical and genetic interactions of yeast Cwc21p, an ortholog of human SRm300/SRRM2, suggest a role at the catalytic center of the spliceosome. RNA 15: 2161-2173.

Häcker I, Sander B, Golas MM, Wolf E, Karagöz E, Kastner B, Stark H, Fabrizio P, Lührmann R. 2008. Localization of Prp8, Brr2, Snu114 and U4/U6 proteins in the yeast tri-snRNP by electron microscopy. Nat Struct Mol Biol 15: 1206-1212.

Hegele A, Kamburov A, Grossmann A, Sourlis C, Wowro S, Weimann M, Will CL, Pena V, Lührmann R, Stelzl U. 2012. Dynamic protein-protein interaction wiring of the human spliceosome. Mol Cell 45: 567-580.

Hilliker AK, Staley JP. 2004. Multiple functions for the invariant AGC triad of U6 snRNA. RNA 10: 921-928. 
Hogg R, McGrail JC, O'Keefe RT. 2010. The function of the NineTeen Complex (NTC) in regulating spliceosome conformations and fidelity during pre-mRNA splicing. Biochem Soc Trans 38: $1110-1115$.

Horowitz DS. 2012. The mechanism of the second step of pre-mRNA splicing. Wiley Interdiscip Rev RNA 3: 331-350.

Kandels-Lewis S, Séraphin B. 1993. Involvement of U6 snRNA in $5^{\prime}$ splice site selection. Science 262: 2035-2039.

Kastner B, Fischer N, Golas MM, Sander B, Dube P, Boehringer D, Hartmuth K, Deckert J, Hauer F, Wolf E, et al. 2008. GraFix: sample preparation for single-particle electron cryomicroscopy. Nat Methods 5: 53-55.

Keating KS, Toor N, Perlman PS, Pyle AM. 2010. A structural analysis of the group II intron active site and implications for the spliceosome. RNA 16: 1-9.

Kim SH, Lin RJ. 1996. Spliceosome activation by PRP2 ATPase prior to the first transesterification reaction of pre-mRNA splicing. Mol Cell Biol 16: 6810-6819.

Kramer K, Sachsenberg T, Beckmann BM, Qamar S, Boon KL, Hentze MW, Kohlbacher O, Urlaub H. 2014. Photo-cross-linking and high-resolution mass spectrometry for assignment of RNAbinding sites in RNA-binding proteins. Nat Methods 11: 10641070.

Lardelli RM, Thompson JX, Yates JR III, John R, Stevens SW. 2010. Release of SF3 from the intron branchpoint activates the first step of pre-mRNA splicing. RNA 16: 516-528.

Lesser CF, Guthrie C. 1993. Mutations in U6 snRNA that alter splice site specificity: implications for the active site. Science 262: 19821988.

Liu HL, Cheng SC. 2012. The interaction of Prp2 with a defined region of the intron is required for the first splicing reaction. Mol Cell Biol 32: $5056-5066$.

Madhani HD, Guthrie C. 1994. Dynamic RNA-RNA interactions in the spliceosome. Annu Rev Genet 28: 1-26.

McConnell TS, Steitz JA. 2001. Proximity of the invariant loop of U5 snRNA to the second intron residue during pre-mRNA splicing. EMBO J 20: 3577-3586.

McGrail JC, Krause A, O'Keefe RT. 2009. The RNA binding protein Cwc2 interacts directly with the U6 snRNA to link the nineteen complex to the spliceosome during pre-mRNA splicing. Nucleic Acids Res 37: 4205-4217.

McPheeters DS, Muhlenkamp P. 2003. Spatial organization of proteinRNA interactions in the branch site- $3^{\prime}$ splice site region during premRNA splicing in yeast. Mol Cell Biol 23: 4174-4186.

Mefford MA, Staley JP. 2009. Evidence that U2/U6 helix I promotes both catalytic steps of pre-mRNA splicing and rearranges in between these steps. RNA 15: 1386-1397.

Mozaffari-Jovin S, Wandersleben T, Santos KF, Will CL, Lührmann R, Wahl MC. 2013. Inhibition of RNA helicase Brr2 by the C-terminal tail of the spliceosomal protein Prp8. Science 341: 80-84.

Nguyen THD, Li J, Galej WP, Oshikane H, Newman AJ, Nagai K. 2013. Structural basis of Brr2-Prp8 interactions and implications for U5 snRNP biogenesis and the spliceosome active site. Structure 21: 910-919.

Nguyen THD, Galej WP, Bai XC, Savva CG, Newman AJ, Scheres SHW, Nagai K. 2015. The architecture of the spliceosomal U4/U6.U5 trisnRNP. Nature 523: 47-52.

Nguyen THD, Galej WP, Bai XC, Oubridge C, Newman AJ, Scheres SHW, Nagai K. 2016a. Cryo-EM structure of the yeast U4/ U6.U5 tri-snRNP at $3.7 \AA$ resolution. Nature 530: 298-302.

Nguyen THD, Galej WP, Fica SM, Lin P-C, Newman AJ, Nagai K. 2016b. CryoEM structures of two spliceosomal complexes: starter and dessert at the spliceosome feast. Curr Opin Struct Biol 36: 48-57.

Ohrt T, Prior M, Dannenberg J, Odenwälder P, Dybkov O, Rasche N, Schmitzová J, Gregor I, Fabrizio P, Enderlein J, et al. 2012. Prp2-mediated protein rearrangements at the catalytic core of the spliceosome as revealed by dcFCCS. RNA 18: 1244-1256.
Price SR, Evans PR, Nagai K. 1998. Crystal structure of the spliceosomal $\mathrm{U} 2 \mathrm{~B}^{\prime \prime}-\mathrm{U} 2 \mathrm{~A}^{\prime}$ protein complex bound to a fragment of U2 small nuclear RNA. Nature 394: 645-650.

Puig O, Caspary F, Rigaut G, Rutz B, Bouveret E, Bragado-Nilsson E, Wilm M, Séraphin B. 2001. The tandem affinity purification (TAP) method: a general procedure of protein complex purification. Methods 24: 218-229.

Raghunathan PL, Guthrie C. 1998. RNA unwinding in U4/U6 snRNPs requires ATP hydrolysis and the DEIH-box splicing factor Brr2. Curr Biol 8: 847-855.

Rasche N, Dybkov O, Schmitzová J, Akyildiz B, Fabrizio P, Lührmann R. 2012. Cwc2 and its human homologue RBM22 promote an active conformation of the spliceosome catalytic centre. EMBO $J$ 31: 1591-1604.

Reddy R, Ro-Choi TS, Henning D, Busch H. 1974. Primary sequence of U-1 nuclear ribonucleic acid of Novikoff hepatoma ascites cells. $J$ Biol Chem 249: 6486-6494.

Rigaut G, Shevchenko A, Rutz B, Wilm M, Mann M, Séraphin B. 1999. A generic protein purification method for protein complex characterization and proteome exploration. Nat Biotechnol 17: 10301032 .

Rigo N, Sun C, Fabrizio P, Kastner B, Lührmann R. 2015. Protein localisation by electron microscopy reveals the architecture of the yeast spliceosomal B complex. EMBO J 34: 3059-3073.

Roy J, Kim K, Maddock JR, Anthony JG, Woolford JL Jr. 1995. The final stages of spliceosome maturation require Spp2p that can interact with the DEAH box protein Prp2p and promote step 1 of splicing. RNA 1: 375-390.

Schneider C, Agafonov DE, Schmitzová J, Hartmuth K, Fabrizio P, Lührmann R. 2015. Dynamic contacts of U2, RES, Cwc25, Prp8 and Prp45 proteins with the pre-mRNA branch-site and 3' splice site during catalytic activation and step 1 catalysis in yeast spliceosomes. PLoS Genet 11: e1005539.

Silverman EJ, Maeda A, Wei J, Smith P, Beggs JD, Lin RJ. 2004. Interaction between a G-patch protein and a spliceosomal DEXD/ H-box ATPase that is critical for splicing. Mol Cell Biol 24: 10101-10110.

Silverton EW, Navia MA, Davies DR. 1977. Three-dimensional structure of an intact human immunoglobulin. Proc Natl Acad Sci 74: 5140-5144.

Singh R, Reddy R. 1989. $\gamma$-Monomethyl phosphate: a cap structure in spliceosomal U6 small nuclear RNA. Proc Natl Acad Sci 86: $8280-8283$.

Sontheimer EJ, Steitz JA. 1993. The U5 and U6 small nuclear RNAs as active site components of the spliceosome. Science 262: 19891996.

Staley JP, Guthrie C. 1999. An RNA switch at the 5 ' splice site requires ATP and the DEAD box protein Prp28p. Mol Cell 3: 55-64.

Wan R, Yan C, Bai R, Wang L, Huang M, Wong CCL, Shi Y. 2016. The $3.8 \AA$ structure of the U4/U6.U5 tri-snRNP: insights into spliceosome assembly and catalysis. Science 351: 466-475.

Wang Q, He J, Lynn B, Rymond BC. 2005. Interactions of the yeast SF3b splicing factor. Mol Cell Biol 25: 10745-10754.

Warkocki Z, Odenwälder P, Schmitzová J, Platzmann F, Stark H, Urlaub H, Ficner R, Fabrizio P, Lührmann R. 2009. Reconstitution of both steps of Saccharomyces cerevisiae splicing with purified spliceosomal components. Nat Struct Mol Biol 16: 1237-1243.

Warkocki Z, Schneider C, Mozaffari-Jovin S, Schmitzová J, Höbartner C, Fabrizio P, Lührmann R. 2015. The G-patch protein Spp2 couples the spliceosome-stimulated ATPase activity of the DEAH-box protein Prp2 to catalytic activation of the spliceosome. Genes Dev 29: 94-107.

Will CL, Lührmann R. 2011. Spliceosome structure and function. In RNA world (ed. Gesteland RF, Cech TR, Atkins JF), pp. 181-203. Cold Spring Harbor Laboratory Press, Cold Spring Harbor, NY. 
Wolf E, Kastner B, Deckert J, Merz C, Stark H, Lührmann R. 2009. Exon, intron and splice site locations in the spliceosomal B complex. EMBO J 28: 2283-2292.

Wu JA, Manley JL. 1991. Base pairing between U2 and U6 snRNAs is necessary for splicing of a mammalian pre-mRNA. Nature 352: 818-821.

Wyatt JR, Sontheimer EJ, Steitz JA. 1992. Site-specific cross-linking of mammalian U5 snRNP to the $5^{\prime}$ splice site before the first step of pre-mRNA splicing. Genes Dev 6: 2542-2553.
Wysoczański P, Schneider C, Xiang S, Munari F, Trowitzsch S, Wahl MC, Lührmann R, Becker S, Zweckstetter M. 2014. Cooperative structure of the heterotrimeric pre-mRNA retention and splicing complex. Nat Struct Mol Biol 21: 911-918.

Yan C, Hang J, Wan R, Huang M, Wong CCL, Shi Y. 2015. Structure of a yeast spliceosome at 3.6-angstrom resolution. Science 349: 11821191.

Zhou Z, Reed R. 2003. Purification of functional RNA-protein complexes using MS2-MBP. Curr Protoc Mol Biol 63: 27.3.1-27.3.7. 

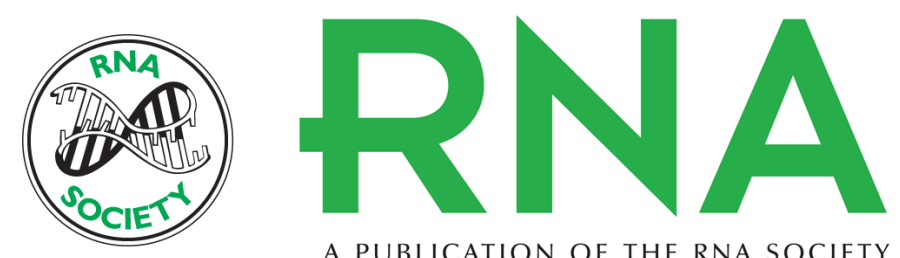

A PUBLICATION OF THE RNA SOCIETY

\section{A protein map of the yeast activated spliceosome as obtained by electron microscopy}

Chengfu Sun, Norbert Rigo, Patrizia Fabrizio, et al.

RNA 2016 22: 1427-1440 originally published online July 1, 2016

Access the most recent version at doi:10.1261/rna.057778.116

\section{Supplemental http://rnajournal.cshlp.org/content/suppl/2016/07/01/rna.057778.116.DC1 \\ Material}

References This article cites 68 articles, 36 of which can be accessed free at: http://rnajournal.cshlp.org/content/22/9/1427.full.html\#ref-list-1

Creative This article is distributed exclusively by the RNA Society for the first 12 months after the Commons full-issue publication date (see http://rnajournal.cshlp.org/site/misc/terms.xhtml). After 12

License months, it is available under a Creative Commons License (Attribution-NonCommercial 4.0 International), as described at http://creativecommons.org/licenses/by-nc/4.0/.

Email Alerting
Service

Receive free email alerts when new articles cite this article - sign up in the box at the top right corner of the article or click here.

To subscribe to $R N A$ go to:

http://rnajournal.cshlp.org/subscriptions 